\title{
KUALITAS KEHIDUPAN KERJA DITINJAU DARI KEPUASAN KERJA DAN PERSEPSI TERHADAP KINERJA
}

\author{
Kurniasari Pratiwi ${ }^{1}$, Fathul Himam ${ }^{2}$ \\ ${ }^{1}$ Akademi Kebidanan Yogyakarta \\ Jl. Parangtritis Km.6 Sewon Bantul \\ ${ }^{2}$ Fakultas Psikologi Universitas Gadjah Mada \\ Jl. Humaniora no.1 Yogyakarta \\ kiky_kurniasari@rocketmail.com
}

\begin{abstract}
Nowadays, employees are more aware with the quality of life issue than before. Consequently, quality of work life (QWL) also becomes an important issue in the management of human resources in an organization. Higher QWL in workplace brings positive implication to the organizational performance. This study aims to investigate the role of work satisfaction and perceived work performance towards QWL on civil servants (PNS). This study used a survey method; it was conducted in the Bantul municipality, Yogyakarta. The population of civil servants in this municipality is 600 employees. This study comprised 150 employees as study sample that was approached using purposive sampling method. Three instruments were used to collect data: Quality of Work Life (QWL) scale (20 items; $\alpha=0,867)$; Work Satisfaction scale (22 items; $\alpha=0,837$ ); and Perceived Work Performance scale (20 items; $\alpha=0,904)$. Multiple regressions was used to analyze the data. The results showed work satisfaction and perceived work performance had significant affects towards QWL ( $F=17,852 ; p<0,001)$.
\end{abstract}

Keywords: quality of work life (QWL), work satisfaction, work performance, civil servant, Bantul

\begin{abstract}
Abstrak
Seiring perkembangan jaman, saat ini karyawan cenderung lebih memperhatikan kualitas hidup (quality of life) dibanding tahun-tahun sebelumnya. Konsekuensi dari perubahan tersebut adalah isu-isu mengenai kualitas kehidupan kerja (quality of work life/QWL) menjadi persoalan penting bagi pengembangan sumber daya manusia dalam organisasi. QWL yang tinggi di tempat kerja berimplikasi positif kepada organisasi. Penelitian ini bertujuan untuk menyelidiki peran kepuasan kerja dan persepsi terhadap kinerja terhadap peningkatan $Q W L$. Penelitian ini menggunakan metode survei dengan populasi PNS Pemerintah Kabupaten Bantul berjumlah 600 orang. Sampel penelitian ini sejumlah 150 orang yang ditentukan dengan teknik purposive sampling. Instrumen penelitian yang digunakan adalah Skala Kualitas Kehidupan Kerja (20 aitem; $\alpha=0$,867); Skala Kepuasan Kerja (22 aitem; $\alpha=0$,837); dan Skala Persepsi terhadap Kinerja (20 aitem; $\alpha=0,904$ ). Analisis data dilakukan dengan analisis regresi ganda. Hasil penelitian menunjukkan adanya pengaruh yang signifikan antara kepuasan kerja dan persepsi terhadap kinerja terhadap QWL ( $F=17,852 ; \mathrm{p}<0,001$ ).
\end{abstract}

Kata kunci: kualitas kehidupan kerja, kepuasan kerja, kinerja, PNS, Pemda Bantul

\section{PENDAHULUAN}

Seiring perkembangan jaman, saat ini karyawan cenderung lebih memperhatikan kualitas hidup (quality of life) dibanding tahun-tahun sebelumnya, sehingga konsekuensinya isu-isu mengenai kualitas hidup pekerja (Quality of work life/QWL) menjadi persoalan penting bagi pengembangan sumber daya manusia dalam organisasi (Lian, Lin, \& Wu, 2007). Pendapat senada dikemukakan oleh Greenberg \& Baron seperti yang dikutip oleh Kembaren (2009), bahwa akhir-akhir ini terdapat 
kecenderungan untuk secara sistematis meningkatkan kualitas hidup melalui pengalaman kerja. Hal tersebut dikarenakan semakin banyak orang yang menuntut pemenuhan kebutuhan pribadi dalam bekerja (White, 2007).

Beberapa peneliti seperti Sirgy, Efraty, Siegel, dan Lee (2001) secara khusus meneliti mengenai pengukuran QWL berdasarkan teori kebutuhan Maslow dan teori kelebihan (spillover theories). Pengukuran tersebut dirancang untuk mengungkap sejauh mana lingkungan kerja, persyaratan kerja, perilaku supervisi, dan program-program penunjang dalam organisasi yang dianggap dapat memenuhi kebutuhan seorang karyawan. Pengukuran tersebut berdasarkan tujuh dimensi kebutuhan Maslow, yaitu kebutuhan akan kesehatan dan keamanan, kebutuhan ekonomi, kebutuhan sosial, pengakuan dan penghargaan kerja, aktualisasi, kebutuhan akan pengetahuan, dan kebutuhan estetika.

Hasil survei yang dilakukan oleh European Foundation for the Improvement of Living and Working Conditions (2007) menunjukkan bahwa upaya untuk memperoleh kehidupan kerja yang lebih baik serta pencapaian kesejahteraan (wellbeing) bagi karyawan menjadi masalah yang semakin urgent untuk lebih diperhatikan. Selain masalah lingkungan fisik yang harus terus ditangani, masalah sosial dan psikologis juga mulai muncul.

Berdasarkan penelitian yang dilakukan oleh tim survei QWL selama 30 tahun di Amerika Serikat secara konsisten menunjukkan hasil bahwa QWL tinggi di tempat kerja dapat menurunkan tingkat stres di tempat kerja, meningkatkan produktivitas dan loyalitas terhadap perusahaan (Team QWL Survey, 2007). Melalui survey tersebut diketahui berbagai faktor yang mempengaruhi $Q W L$ diantaranya adalah konteks internasional, konteks nasional, situasi organisasi, tempat kerja, faktor pekerjaan, faktor keluarga, serta faktor individu yang bersangkutan. Penelitian terakhir yang dilakukan oleh tim survei QWL (2007) diperoleh hasil bahwa faktor psikologis yaitu kepuasan kerja dapat berpengaruh terhadap QWL.

Penelitian lain dilakukan oleh Lian, Lin, dan Wu (2007) diperoleh hasil bahwa kepuasan kerja berpengaruh secara signifikan terhadap QWL. Pendapat senada dikemukakan oleh Sudarsono (2007) bahwa kepuasan kerja berkorelasi positif terhadap $Q W L$. Semakin tinggi kepuasan kerja seseorang, semakin tinggi pula $Q W L$-nya. Kepuasan kerja sangat kuat pengaruhnya terhadap QWL berupa karir, pendapatan, keamanan, sosial dan jabatan yang diharapkan. Efraty dan Sirgy (1990) dalam hasil penelitiannya juga membuktikan bahwa kepuasan kerja, identifikasi organisasi, keterlibatan kerja, usaha kerja, serta persepsi terhadap kinerja berhubungan positif terhadap QWL.

Menurut Robbins (2003), kepuasan kerja merupakan sikap seorang terhadap pekerjaannya dan dapat dijadikan indicator untuk melihat kondisi suatu organisasi. Gibson, Ivancevich dan Donelly (1997) menyatakan bahwa kepuasan yang diperoleh karyawan dapat mempengaruhi efektivitas organisasi. Agar organisasi mampu bersaing dan berhasil mencapai tujuannya, penting untuk memberikan perhatian pada SDM, terutama karyawan sebagai aset utama organisasi. Perusahaan harus mengupayakan kepuasan kerja bagi karyawan agar kinerja mereka meningkat, dan akhirnya tujuan perusahaan dapat tercapai.

Kinerja pegawai merupakan gabungan dari kemampuan, usaha, dan kesempatan yang dapat diukur dari akibat yang dihasilkan, kinerja dapat dikatakan sebagai hasil kerja yang telah dilakukan oleh seseorang. Oleh karena itu, kinerja dapat didefinisikan 
sebagai perilaku-perilaku atau tindakantindakan yang relevan terhadap tercapainya tujuan organisasi (VandeWalle, Heslin, \& Latham, 2005). Pada kenyataannya kinerja pegawai negeri khususnya pegawai pemerintah daerah (Pemda) sering dinilai kurang memuaskan karena citra dan budaya yang terbangun selama ini adalah menjadi pegawai negeri sipil lebih santai dan nyaman dalam berkerja. Maka banyak terjadi perilaku-perilaku seperti tidak disiplin, bekerja asal-asalan dan sebagainya. Secara umum, beberapa perilaku negative yang ditampakkan oleh oknum pegawai Pemda adalah sikap negatif pada saat bekerja, seperti urusan yang berbelit-belit, rumit akibat birokrasi yang kaku, tidak efektif dan efisien, serta reaktif dibandingkan proaktif. Permasalahan ini banyak ditemukan di pemerintahan daerah di berbagai kabupaten di Indonesia. Studi yang diangkat oleh Soeprapto, Ribawanto, dan Hanafi (2000) menemukan salah satu alternatif solusi untuk mengatasi permasalahan aparatur pemerintah daerah yakni dengan meningkatkan QWL.

Kualitas kehidupan kerja (QWL) merupakan upaya menggabungkan desain pekerjaan dengan lingkungan kerja. Hal ini dapat diupayakan melalui pemenuhan kepuasan kerja, meningkatkan sikap kerja yang positif, serta kinerja (Soeprapto, Ribawanto \& Hanafi. 2000). Berdasarkan wawancara dan observasi awal yang dilakukan peneliti terhadap beberapa Pegawai Pemerintah Daerah di Yogyakarta, serta didukung data laporan evaluasi tahunan oleh pemerintah setempat (2009), dapat disimpulkan adanya indikasi $Q W L$ yang rendah. Hal tersebut dibuktikan dengan tingkat absensi yang cukup tinggi, kualitas pekerjaan yang asalasalan, prosedur yang berbelit-belit, dan perilaku tidak disiplin. Oleh karena itu dapat disimpulkan bahwa QWL pada pegawai Pemda secara umum cenderung memprihatinkan.
Cumming dan Worley (2005) mendefinisikan QWL sebagai hubungan antara reaksi kerja seseorang, terutama yang berhubungan dengan kepuasan personal dalam pekerjaan. Teori ini fokus pada konsekuensi personal terhadap pengalaman kerja dan bagaimana mengubah kerja untuk memenuhi kebutuhan personal. Pendapat senada dikemukakan oleh Bernadin dan Russel (1993) yang menyatakan QWL berhubungan dengan pengalaman individu dalam memperoleh kepuasan, peningkatan motivasi, keterlibatan kerja, dan komitmen terhadap kehidupan kerja. QWL adalah tingkatan dimana individu mendapat kepuasan dalam pemenuhan kebutuhan personal, seperti kebutuhan akan kebebasan ketika bekerja dalam organisasi.

Cascio (1998) menjelaskan dua cara untuk melihat arti QWL, yaitu (1) membandingkan $Q W L$ dengan kondisi organisasi yang sebenarnya seperti penerapan kebijakan perusahaan mengenai promosi kerja, pengawasan yang demokratis, keterlibatan, karyawan, dan kondisi kerja yang aman; (2) membandingkan QWL dengan persepsi karyawan bahwa mereka merasa aman, terpenuhi kebutuhan personalnya serta mampu untuk tumbuh dan berkembang sebagai manusia.

Aspek-aspek QWL dirumuskan sebagai berikut (Flippo, 1984; Werther \& Davis, 1989; Zin, 2004): kesempatan untuk berkembang, relasi sosial, partisipasi kerja, serta kondisi kerja yang baik dan layak. Sedangkan faktor-faktor yang mempengaruhi QWL (survei QWL team, 2007) adalah konteks internasional, faktor kondisi keluarga, faktor personal, serta pekerjaan itu sendiri.

Wexley dan Yukl (1988), Gibson, Ivancevich, \& Donelly (1997), serta Cascio (2003) menjelaskan bahwa kepuasan kerja merupakan keadaan internal individu 
berupa perasaan dan sikap positif akan pekerjaannya. Lebih lanjut dijelaskan bahwa kepuasan kerja secara umum merupakan sikap terhadap pekerjaan yang didasarkan pada evaluasi terhadap aspekaspek yang berbeda bagi pekerja. Sikap seseorang terhadap pekerjaannya tersebut mengambarkan pengalaman-pengalaman menyenangkan atau tidak menyenangkan dalam pekerjaan dan harapan-harapan mengenai pengalaman mendatang.

Mengacu pada beberapa pendapat ahli seperti Luthans (2006), serta King dan Hautaluoma (2001), Skala Kepuasan Kerja dalam penelitian ini dikembangkan berdasarkan aspek-aspek kepuasan terhadap pekerjaan, kepuasan terhadap imbalan, kepuasan terhadap kesempatan promosi, kepuasan terhadap atasan dan kepuasan terhadap rekan kerja.

Robbins (2003) menyatakan bahwa terdapat beberapa faktor yang menimbulkan kepuasan kerja, yaitu kerja yang secara mental menantang, ganjaran yang pantas, kondisi yang mendukung, rekan sekerja yang mendukung, kesesuaian antara kepribadian dan pekerjaan. Pendapat lain dikemukakan oleh Wexley and Yukl (1977), bahwa kepuasan kerja ditentukan atau dipengaruhi oleh tiga faktor yaitu karakteristik individu, variabel situasional, dan karakteristik pekerjaan.

Menurut Bernadin dan Russell (1998), kinerja didefinisikan sebagai catatan dari outcomes yang dihasilkan sesuai dengan fungsi pekerjaan secara spesifik atau aktivitas selama periode waktu tertentu. Kinerja seorang individu merupakan gabungan dari kemampuan, usaha, dan kesempatan, yang dapat diukur dari akibat yang dihasilkan. Pendapat senada dikemukakan oleh VandeWalle, Heslin, \& Latham (2005) bahwa kinerja merupakan hasil kerja yang telah dilakukan seseorang, yaitu merupakan gabungan dari kemam- puan, usaha dan kesempatan yang dapat diukur dari akibat yang dihasilkan. Oleh karena itu kinerja dapat didefinisikan sebagai perilaku-perilaku atau tindakantindakan yang relevan terhadap tercapainya tujuan organisasi. Gibson, Ivancevich, dan Donelly (1997) menjelaskan bahwa kinerja adalah hasil kerja yang terkait dengan tujuan organisasi seperti kualitas, efisiensi, dan kriteria keefektifan lain yang dicapai selama periode tertentu melalui usaha yang membutuhkan kemampuan dan keterampilan serta pengalaman.

Berdasarkan definisi di atas, dapat ditarik kesimpulan bahwa persepsi kinerja merupakan proses mental seseorang untuk mengenali stimulus atau memahami informasi tentang hasil kerja yang dapat dicapai yaitu berupa perilaku-perilaku atau tindakan-tindakan yang relevan terhadap tercapainya tujuan organisasi. Hasil kerja tersebut dicapai melalui usaha dengan kemampuan dan keterampilan serta pengalaman yang dapat diukur dalam periode waktu tertentu.

Persepsi kinerja pada penelitian ini mengacu pada aspek-aspek yang dikemukakan oleh Dwiyanto yang dikutip oleh Saraswati (2006) yaitu terdiri tiga aspek yaitu (1) aspek responsivitas, (2) aspek responsibilitas, dan (3) aspek akuntabilitas.

Aspek responsivitas adalah kemampuan organisasi untuk mengenali kebutuhan masyarakat, menyusun agenda prioritas pelayanan dan mengembangkan programprogram pelayanan masyarakat sesuai dengan kebutuhan dan aspirasi masyarakat. Aspek responsibilitas menunjuk pada keselarasan antara program dan kegiatan pelayanan dengan kebutuhan dan aspirasi masyarakat, untuk mencapai visi dan misi organisasi. Aspek akuntabilitas adalah pengukuran usaha para wakil rakyat atau pejabat politisi dan tokok-tokoh masyarakat 
dalam memperjuangkan aspirasi masyarakat.

Jordan, Ashkanasy, \& Hartel (2002) menjelaskan bahwa kinerja yang dirasakan oleh pegawai dipengaruhi oleh dua faktor yaitu faktor eksternal dan faktor internal. Lebih lanjut dijelaskan bahwa faktor eksternal merupakan faktor kontekstual yang lebih erat berkaitan dengan lingkungan kerja, kebijakan sumber daya manusia dan prakteknya, desain kerja dan isu teknologi, serta budaya organisasi. Sedangkan faktor internal individu yang turut mempengaruhi kinerja diantaranya adalah efikasi diri, pekerjaan yang kompetitif atau menantang, serta faktor emosi. Hofmann \& Jones (2005) berpendapat bahwa kinerja pegawai dipengaruhi oleh dua faktor yaitu (1) faktor personal, yaitu hal-hal dari dalam individu atau yang melekat pada individu; dan (2) faktor situasional, yaitu faktor yang berasal dari luar individu.

Kepuasan kerja merupakan keadaan internal individu berupa perasaan dan sikap positif atas pekerjaannya. Kepuasan kerja merupakan suatu perasaan menyenangkan, yang timbul sebagai akibat dari persepsi karyawan, bahwa dengan menyelesaikan tugas atau dengan berusaha untuk menyelesaikan pekerjaan memiliki nilai yang penting dalam pekerjaan tersebut (Cascio, 2003). Aspek-aspek kepuasan kerja terdiri dari kepuasan terhadap pekerjaan, kepuasan terhadap imbalan, kepuasan terhadap kesempatan promosi, kepuasan terhadap atasan dan kepuasan terhadap rekan kerja. Kepuasan kerja dapat dipengaruhi oleh tiga kelompok faktor-faktor, yaitu karakteristik individu, variabel situasional, dan karakteristik pekerjaan (Wexley \& Yukl, 1988).

Kepuasan kerja terkait erat dengan $Q W L$. Hal ini ditunjukkan oleh hasil penelitian Lian, Lin, dan Wu (2007) yang menemukan bahwa kepuasan kerja berpengaruh secara signifikan terhadap QWL. Pendapat senada dikemukakan oleh Sudarsono (2007), bahwa kepuasan kerja secara signifikan berkorelasi positif terhadap QWL. Semakin tinggi kepuasan kerja seseorang maka semakin tinggi pula QWL-nya. Kepuasan kerja berpengaruh kuat terhadap QWL dalam hal karir, pendapatan, keamanan, sosial dan jabatan yang diharapkan. Rose, Beh, Ulil, \& Idris (2006) mendukung penelitian ini dengan penelitiannya tentang implikasinya QWL terhadap dimensi karier. Hasil penelitian tersebut membuktikan bahwa QWL berkorelasi dengan kepuasan karir, pencapaian karir, dan keseimbangan karir.

Selain kepuasan kerja, faktor lain yang diduga mempengaruhi QWL adalah kinerja karyawan. Lian, Lin, dan Wu (2007) berpendapat jika karyawan memiliki kepuasan kerja dan kinerja yang tinggi maka QWL-nya pun akan meningkat. Efraty dan Sirgy (1990) juga membuktikan bahwa kepuasan kerja, identifikasi organisasi, keterlibatan kerja, usaha kerja, serta persepsi terhadap kinerja berhubungan positif dengan QWL.

Upaya peningkatan QWL dapat dilakukan dengan cara melibatkan karyawan secara langsung dalam pengambilan keputusan perusahaan, memberikan kompensasi sesuai latar belakang pendidikan dan beban tugas, menciptakan lingkungan kerja yang aman dan kondusif, serta menjalin kerjasama antara manajemen dengan karyawan dalam menjalankan organisasi (Cascio, 1998).

Hasil penelitian team QWL di Inggris (2007) menunjukkan bahwa QWL dipengaruhi oleh konteks internasional, nasional, organisasi, tempat kerja, individu, keluarga dan pekerjaan itu sendiri. Kepuasan kerja berpengaruh terhadap QWL dalam konteks lingkungan kerja. Hasil penelitian Soeprapto, Ribawanto, dan Hanafi (2000) menyimpulan bahwa peningkatan QWL dapat diupayakan dengan cara 
memaksimalkan kepuasan kerja, meningkatkan sikap kerja yang positif, serta memperbaiki kinerja.

Faktor lain yang mempengaruhi QWL diantaranya adalah kesempatan karyawan untuk berkembang dalam perusahaan, hubungan kerja yang terbina antara atasan, teman kerja, serta bawahan, kondisi tempat kerja yang kondusif, serta partisipasi karyawan dalam organisasi. Menurut Meyer, Irving \& Allen (dalam Saraswati, 2006), pengalaman kerja yang meliputi rasa aman dan nyaman dalam bekerja, kesempatan untuk bekerja dan berkompetisi, dan kebebasan dalam pengambilan keputusan dapat mempengaruhi timbulnya QWL.

Dengan demikian dapat disimpulkan bahwa terdapat $Q W L$ yang tinggi pada pegawai bila pegawai tersebut memperoleh kepuasan dalam pemenuhan kebutuhan personal dalam organisasi, memperoleh rasa aman, merasa berpartisipasi dalam pengambilan keputusan, serta memiliki kesempatan untuk berkembang. Hal ini juga dapat diterapkan di Pemda Kabupaten Bantul, yaitu QWL pada karyawan dapat ditingkatkan, antara lain dengan cara mengupayakan pemenuhan kebutuhan personal dalam organisasi, pemenuhan kebutuhan akan rasa aman, memberikan kesempatan berpartisipasi dalam pengambilan keputusan, serta memberikan kesempatan untuk berkembang.

Penelitian ini bertujuan untuk mengetahui ada/tidaknya pengaruh kepuasan kerja dan persepsi terhadap kinerja dengan $Q W L$ pada pegawai Pemda Kabupaten Bantul.

\section{METODE}

Penelitian ini menggunakan metode survei dan dilakukan pada Pegawai Negeri Sipil (PNS) Pemerintah Kabupaten Bantul.
Populasi PNS yang berkantor di gedung Parasamya Kabupaten Bantul berjumlah 600 orang. Jumlah PNS yang sesuai dengan karakteristik subjek penelitian adalah 531. Jumlah responden untuk uji coba adalah 129 orang, dan yang digunakan untuk subjek penelitian berjumah 150orang. Teknik pemilihan subjek yang digunakan adalah purposive sampling.

Data dikumpulkan menggunakan tiga skala psikologis: (1) Skala QWL (20 aitem valid; $\alpha=0,867)$; (2) Skala Kepuasan Kerja (22 aitem valid; $\alpha=0,837$ ); dan (3) Skala Persepsi Kinerja (20 aitem valid; $\alpha=$ 0,904). Analisis regresi berganda digunakan untuk menganalisis korelasi kepuasan kerja dan persepsi kinerja terhadap $Q W L$.

\section{HASIL DAN PEMBAHASAN}

Berdasarkan hasil analisis data diketahui bahwa kepuasan kerja dan persepsi terhadap kinerja secara bersama-sama berpengaruh secara signifikan terhadap QWL. Berdasarkan Hasil analisis data diperoleh nilai $F$ sebesar 17,852 lebih besar dari $\mathrm{F}$ tabel 4,778 dengan nilai probabilitas $\mathrm{p}=0,000(\mathrm{p}<0,01)$, hal ini menunjukkan bahwa secara bersama-sama kepuasan kerja dan kinerja berpengaruh terhadap QWL. Koefisien determinasi berganda $\left(\mathrm{R}^{2}\right)$ adalah 0,221 yang berarti 22,1\% dari QWL pegawai dipengaruhi oleh kepuasan kerja dan persepsi kinerja. Uji analisis parsial menunjukkan kepuasan kerja berpengaruh signifikan terhadap QWL ( $\mathrm{t}=2$ 2,709; $\mathrm{p}<$ 0,05 ) dengan sumbangan pengaruh sebesar 24\%. Persepsi kinerja berpengaruh secara signifikan terhadap QWL $(\mathrm{t}=3,498$; $\mathrm{p}=0,000$ ) dengan sum-bangan pengaruh sebesar $30,9 \%$.

Dengan demikian dapat disimpulkan bahwa kepuasan kerja dan persepsi kinerja secara bersama-sama memberi pengaruh signifikan terhadap QWL. Persepsi kinerja 
memiliki pengaruh yang lebih besar terhadap QWL dibandingkan dengan pengaruh kepuasan kerja terhadap QWL. Temuan ini tentunya memperlihatkan betapa pentingnya faktor-faktor intrinsik pegawai diantaranya kepuasan kerja dan persepsi terhadap kinerja dalam menentukan QWL pegawai khususnya dalam lingkungan Pemerintahan Daerah. Hal tersebut bisa menjadi masukan kepada pihak pemerintah daerah khususnya Badan Kepegawaian Daerah yang mengelola Sumber Daya Manusia dilingkungan pemerintahan dalam menyusun work design melalui pendekatan sosio technical approach dengan cara memberi perhatian lebih terhadap faktor kepuasan kerja dan kinerja pegawai sehingga QWL pegawainya diharapkan dapat terpelihara. QWL yang tinggi pada pegawai dapat memberikan pengaruh positif terhadap organisasi, hal ini sesuai dengan hasil penelitian yang dilakukan oleh tim survey QWL selama 30 tahun di US secara konsisten menunjukkan hasil bahwa QWL yang tinggi di tempat kerja dapat menurunkan tingkat stress di tempat kerja, meningkatkan produktivitas dan loyalitas terhadap organisasi maupun perusahaan (QWL survey, 2007).

\section{KESIMPULAN}

Hasil penelitian ini menunjukkan kepuasan kerja dan persepsi terhadap kinerja berpengaruh secara signifikan terhadap Quality of Work Life (QWL) pada PNS Pemda Bantul (nilai F hitung sebesar 17,852 lebih besar dari $F$ tabel 4,778 dengan nilai probabilitas $p=0,000(p<0,01)$.

\section{DAFTAR PUSTAKA}

Bernadin, J. H. \& Russell, J. E. (1998). Human resource management: An experimential approach. New York: Mc Graw Hill Companies.
Cascio, W. F. (1998). Managing human resources: Productivity, quality of work life, profits. Boston: McGraw-Hill.

Cascio, W. F. (2003). Applied psychology in human resource management. New York: Prentice Hall.

Efraty, D. \& Sirgy, M. J. (1990). The effect of quality of working life (QWL) on employee behavioral responses. Journal of Social Indicators Research, 22, 31-47.

Gibson, J. L., Ivancevich, J. M., \& Donelly, J. H. (1997). Organizations: Behavior, structure, and processes. New York: McGraw-Hill.

Flippo, E. B. (1984). Personnel Management. Singapore: McGraw-Hill.

Hofmann, D. A. \& Jones, L. M. (2005). Leadership, collective personality, and performance. Journal of Applied Psychology, 3(90), 509-522.

Jordan, P. J., Ashkanasy, N. M., \& Hartel, C. E. J. (2002). Emotional intelligence as a moderator of emotional and behavioral reaktions to job insecurity. Academy of Management Review, 3(27), 361-372.

Kembaren, E. M. (2009). Gambaran quality of work life (QWL): Ditinjau dari perbedaan jenis pekerjaan dan gender. Jakarta: Fakultas Psikologi Universitas Atma Jaya.

King, W. L. \& Hautalouma, J. E. (2001). Comparison of job satisfaction, life satisfaction, and performance of overeducated and other worker. The Journal of Social Psychologhy, 127 (5), 421-433. 
Lian, W., Lin, M., \& Wu, K. (2007). Job stress, job satisfaction and life satisfaction between managerial and technical is personnel. Proceedings of Business and Information, 4, 1-17.

Luthans, F. (2006). Organizational behavior: Perilaku organisasi. Yogyakarta: Andi offset.

Robbins, S. P. (2003). Organization theory: Structure, design, and applications. Alih bahasa; Jusuf Udaya. Jakarta: Arcan.

Rose, R. C., Beh, L., Uli, J. \& Idris, K. (2006). Quality of work life: implications of career dimensions. Journal of Social Sciences, 2(2), 61-67.

Saraswati, B, (2006). Hubungan antara quality of work life (QWL) dengan komitmen karyawan pada PT. Aseli Dagadu Djogja. Skripsi (tidak diterbitkan). Yogyakarta: Fakultas Psikologi Universitas Gadjah Mada.

Sirgy, M. J., Efraty, D., Siegel, P. \& Lee, D. J. (2001). A new measure of quality of work life (QWL) based on need satisfaction and spillover theories. Social Indicators Research, 55(3), 241302.

Soeprapto, H. R., Ribawanto, H., \& Hanafi, I. (2000). Pengembangan sumber daya aparatur daerah di era reformasi. Jurnal Administrasi Negara, I (1), 46 - 57.

Sudarsono, (2007). Analisa struktural equation (SEM) pada sikap hidup dan pekerjaan PNS di pemerintah Kabupaten Trenggalek. ITS Library: Ebursa.depdiknas.go.id.
Team Quality of Work Life Survey. (2007). European foundation for the improvement of living and working conditions: Finnish quality of work life surveys. Diambil dari www.eurofound.europa.eu

Tim. (2009). Data laporan evaluasi tahunan Badan Kepegawaian Daerah (BKD) Kebupaten Bantul. Arsip (Tidak diterbitkan). Yogyakarta: Pemerintah Daerah Kabupaten Bantul.

VandeWalle, D., Heslin, P. A., \& Latham, G. P. (2005). The effect of implicit person theory on performance appraisals. Journal Applied Psychologhy, 5(90), 842-856.

Werther, W. B. \& Davis, Jr. K. (1989). Human resources and personnel management. Singapore: McGraw-Hill.

Wexley, K. N. \& Yukl, L. A. (1988). Organizational behavior and personnel psychology. Boston: Richad D. Irwin, Inc.

White, A. G. (2007). A global projection of subjective well-being: A challenge to positive psychology? Psychtalk, 56, 1720.

Zin, R. M. (2004). Perception of professional engineers toward of work life and organizational commitment: A case study. Gadjah Mada Internasional Journal of Business,6(3), 323-334. 